\title{
IT-Budgeting Processes in Swiss Banks and How They Are Influenced by Rapidly Changing Regulatory Requirements
}

\author{
Christian Hitz ${ }^{1}$, Mike Krey ${ }^{2}$, Marius Albath ${ }^{3}$, Robin Wyss ${ }^{4}$, and Per Thoma ${ }^{5}$ \\ ${ }^{1}$ Faculty of Business Administration, University of Economics, Prague, Czech Republic \\ 2,3,4,5 Institute of Business Information Technology, ZHAW, Winterthur, Switzerland
}

Correspondence should be addressed to: Christian Hitz;hitc00@vse.cz

Received date: 11 April 2018; Accepted date: 14 June 2018; published date: 22 November 2018

Academic Editor: Iwona Pisz

Copyright (C) 2018. Christian Hitz, Mike Krey, Marius Albath, Robin Wyss, and Per Thoma

. Distributed under Creative Commons CC-BY 4.0

\begin{abstract}
The budgeting processes for IT projects in Swiss banks is a subject which has remained almost unexplored to date. For the purpose of this paper, a thorough literature review was conducted to gather information on different budgeting methods and identify the current challenges that banks are facing. To find out how the various budgeting processes of banks support their ability to react to fast-changing market conditions, how they differ from each other, and to identify the main problems of individual budgeting processes, interviews with five banks were conducted. While, on the whole, Swiss banks were found to be wellprepared for fast changes in the markets, a strong link to their IT project budget processes could not be confirmed. In addition, Swiss banks use traditional budgeting methods in combination with improved budgeting methods. A number of problem areas were identified for current budgeting processes; these include planning accuracy as well as implementation and business IT alignment.
\end{abstract}

Keywords: IT-Budgeting, Swiss Banks

\section{Introduction}

Information technology (IT) organizations have been called on to play a greater, more proactive role in all industries (Rümmler, Toggwyler, Bollag, \& Nicollier, 2013). It is therefore not a surprise that Swiss banks are investing money into their IT systems to transform their business and drive innovation. Moreover, the business looks to IT to advance analytics and business intelligence to improve business steering (Rümmler et al., 2013).

This paper presents an analysis of the

Cite this Article as: Christian Hitz, Mike Krey, Marius Albath, Robin Wyss, and Per Thoma (2018)," ITBudgeting Processes in Swiss Banks and How They Are Influenced by Rapidly Changing Regulatory Requirements" Journal of EU Research in Business, Vol. 2018 (2018), Article ID 785563, 
current budgeting processes in Swiss banks. It explores the question whether budgeting methods of Swiss banks to finance their IT projects are efficient and it describes their main advantages and drawbacks. Finally, it aims to explore the ability of Swiss banks to react to fastchanging market conditions.

Following an introduction to the topic in Section 1, Section 2 describes today's state of the art in budgeting processes followed by a description of the Swiss banking sector and its current challenges in Section 3 to provide some background information. Next, Section 4 discusses the research questions derived from the literature review while Section 5 addresses them in more detail. This is followed by a detailed description of the results in Section 6. After discussing the research results and relating them to the research questions in Section 7, Section 8 draws some final conclusions. Future research topics, finally, are proposed in Section 9.

\section{Relevance}

While the Swiss banking sector is in the process of a massive structural transformation (Grass \& Peters, 2016) to adapt to regulatory and market changes, many banks still rely on traditional budgeting methods. To stay competitive, however, Swiss banks need to be ready to deal with future market conditions. Any findings that can help them in these efforts might therefore be relevant for business leaders in Swiss banks.

\section{Theoretical Framework}

For an overview of today's budgeting processes for IT projects in Swiss banks, a literature review was conducted to ensure rigorousness and relevance (Kornmeier, 2007). This literature review focused on two topics:

- State-of-the-art budgeting methods

- Analysis of the Swiss banking market and today's challenges
Qualitative, semi-structured expert interviews were conducted to examine the relevance of the findings, as well as identifying new theories (Jonker \& Pennink, 2010).

\section{State-of-the-Art Budgeting Processes}

\section{Budgeting Process}

Companies develop budgets to monitor progress concerning their goals, help them manage expenses, and predict cash flow and profit (Carlene Cassidy, Kreitner, \& Van Huss, 2014). The budgeting process is an essential component of management control systems. It provides management with a system of planning, coordination, and monitoring (Pidgeon, 2010). In fact, budgeting is considered to be one of the most important and effective tools used in managerial accounting (Pietrzak, 2013).

\section{Budgeting Methods}

Four main budgeting methods were identified in this study, which are described in detail below:

- $\quad$ Traditional budgeting

- $\quad$ Better budgeting

- Zero-based budgeting

- Value based budgeting

- Rolling budgets and forecasts

- $\quad$ Advanced budgeting

- $\quad$ Beyond budgeting

\section{Traditional Budgeting}

Traditional budgeting is also known as incremental budgeting because the process is mainly concerned with the incremental (or marginal) adjustments to the current budgeted allowance. The traditional method takes last year's budget as a base. The current year's budget is prepared by making changes to the previous year's budget by adjusting the expenses based on the inflation rate, consumer demands, market situation, and other factors 
(Pidgeon, 2010).

One of the biggest drawbacks of the traditional method is the fact that budgets increase every year (Rieg, 2015). Nevertheless, most companies still take base their budget on the previous year's budget.

\section{Better Budgeting}

The better budgeting concept involves incremental improvements in traditional budgeting (Rickards, 2008). Three approaches can be distinguished: zerobased budgeting, value-based budgeting, and rolling budgets.

Zero-based budgeting is based on the premise that no budget lines should be carried forward from one period to the next simply because they occurred previously. Instead, everything that is included in the budget must be considered and justified (Pidgeon, 2010). The valuebased budgeting method is a formal and systematic approach to managing the creation of shareholder value over time. All expenditure plans are evaluated as project appraisals and assessed in terms of the shareholder value they create. This method helps to link strategy and shareholder value during the planning process (Rivero, 2013). Rolling budgets are updated periodically when a time period comes to an end. The budget is accurate, constantly forward-looking, and always covers the same time horizon. According to Mejzini and Seidel (2015), budgeting becomes a more or less continuous process. Rolling budgets are more responsive to changing circumstances but require permanent resources to administer (Mejzini \& Seidel, 2015).

\section{AdvancedBudgeting}

The advanced budgeting approach sustainably reduces the time and money spent on planning by shortening the planning process and consistently operationalizing the company strategy and external factors into operational planning (Rieg, 2015). This concept includes the following tasks:

- Reducing the amount of detailed planning content

- Employing a balanced scorecard linking operational and strategic planning

- Rollingbudgets

- Decoupling planning from the company's incentiveschemes

\section{Beyond Budgeting}

The aim of the beyond-budgeting management model is to increase the adaptability of enterprises. By running the company completely without a fixed budget, the model wants to overcome the restrictions of the traditional budgetbased management concept. The beyond budgeting concept introduces new leadership principles based on the principle of the empowerment of managers and employees and new, more adaptive management processes (Mitchell, 2005).

Svenska Handelsbanken famously became the first bank to implement the beyondbudgeting method in 1972. Ever since Dr. Jan Wallander started as its executive director in 1970, the bank has been operating without any budgets. The bank is strongly decentralized and has devolved the responsibility for customers to its branch levels (Mejzini \& Seidel, 2015).

The German discount supermarket chain Aldi North is another well-known example of a company that has succeeded in implementing beyond budgeting. Dieter Brandes, its former CEO and member of the supervisory board, finds budgets superfluous. In his view, controllers have too many ideas and overestimate their competence (Rickards, 2006).

\section{Challenges}

Both the preparation and the use of budgets are not without their difficulties (Rieg, 2015). According to Tanase (2014), today's budgeting processes, which are mainly based on a traditional 
method (Group, 2005), have a number of serious drawbacks:

- $\quad$ They are time-consuming.

- They do not allow a company to seize opportunities.

- They reduce a company's flexibility.

- They reduce the ability to react to changes.

- They do not reflect the company's strategy.

- They are bureaucratic.

- They limit creativity.

The costs of supporting the budgeting process are significant, although most companies are not able to determine how much money has actually been spent (Rieg, 2015). International studies provide mixed results regarding the usefulness of budgets. Some come to the conclusion that the budget as a management tool should be replaced and others claim that budgets are no longer useful within a competitive business environment that constantly changes (Tanase, 2014).

\section{The Swiss Banking Sector}

\section{Banking Institutions}

Switzerland is one of the leading global financial centers, ranking among the most competitive in 2016 (Swiss Banking Association, 2017). The Swiss banking sector contributes significantly to the success of Switzerland as a financial center. Swiss banks are, therefore, one of its key sectors, generating 6 percent, or 35 billion Swiss francs, of value added. In addition, they make an important indirect contribution to general economic development and value creation through basic banking services such as credit financing (Swiss Banking Association, 2015).

The aggregated business success of the banks in Switzerland declined by 3.2 percent to 62.5 billion Swiss francs in 2016 due to negative interest rates, according to the State Secretariat for International Finance (SIF) (2017). In terms of gross profit, there was a loss of 16.8 percent. In contrast, the aggregated balance sheet of the Swiss banking sector raised by 2.5 percent to 3,101 billion Swiss francs.

Furthermore, the number of registered banks declined by the end of 2015. Due to restructuring, acquisitions, and insolvencies of banks, only 266 institutions held a Swiss banking license by the end of 2015 (SIF, 2016) - a third less than twenty years ago (SIF, 2016). By the end of 2016, another five institutions were closed, reducing the number of institutions with an active Swiss banking license to 261 (SIF, 2016). The Swiss banking sector is still the world leader in terms of cross-border wealth management and is forecast to hold this position until 2020, according to a 2016 study of the Boston Consulting Group.

As shown in Table 1 below, the Swiss National Bank (SNB) divides Swiss banks into eight groups: cantonal banks, big banks, regional and saving banks, Raiffeisen banks, foreign banks, private bankers, stock exchange banks, and other banks (Swiss Banking Association, 2017). 
Table 1: Structure of the Swiss banking sector (SNB)

\begin{tabular}{|c|c|c|c|c|c|}
\hline & $\begin{array}{l}\text { Number of } \\
\text { institutions } \\
2015\end{array}$ & $\begin{array}{l}\text { Number of } \\
\text { institutions } \\
2016\end{array}$ & $\begin{array}{l}\text { New } \\
\text { admissions }\end{array}$ & Reallocations & Omissions \\
\hline Cantonal banks & 24 & 24 & & & \\
\hline Big banks & 3 & 4 & 1 & & \\
\hline $\begin{array}{l}\text { Regional banks and } \\
\text { Saving banks }\end{array}$ & 62 & 62 & & & \\
\hline Raiffeisen banks & 1 & 1 & & & \\
\hline Foreign banks & 111 & 107 & 1 & & 5 \\
\hline Private banks & 7 & 6 & & -1 & \\
\hline $\begin{array}{l}\text { Stock exchange } \\
\text { banks }\end{array}$ & 44 & 43 & & 1 & 2 \\
\hline Other banks & 14 & 14 & & & \\
\hline Total & 266 & 261 & 2 & & 7 \\
\hline
\end{tabular}

\section{Challenges}

Changing client needs, new competitors, fast technological development, and new regulations have had a strong impact on the Swiss banking sector (Swiss Banking Association, 2015).

According to the Swiss Banking Association (2017), banks face the following challenges:

- Political challenges

- Digitalization

- New employee skills

- Regulation

These challenges lead to higher costs and demand more investments in digitalization and industrialization projects, which is why the Swiss banking sector is undergoing massive structural transformation (Grass \& Peters, 2016). To address these challenges and stay competitive, Swiss banks are adapting their business models, reducing their staff, and implementing new requirements that affect employees and their job profiles (Grass \& Peters, 2016).

\section{Political Challenges}

To lower the pressure on the Swiss franc, the Swiss National Bank (SNB) decided in 2015 to adopt negative interest rates.
The Swiss Banking Association (2017) described the decision as having a negative effect on the interest margin. The resulting losses were partly compensated by the lending business and fee increases. Additionally, negative interest rates were passed on to institutional and very wealthy clients. In step with the increasing risk of this policy, the effectiveness of other extraordinary monetary policy interventions decreased.

Another challenge for banks as a part of the Swiss financial sector is caused by Brexit, which has led to legal uncertainty in the United Kingdom, a situation that is particularly serious for financial transactions, especially for the distribution of financial services to private customers (Swiss Banking Association, 2017).

In the United States, the new administration is also causing uncertainty. Issues such as regulatory degradation and tax cuts as well as renegotiation and unilateral measures concerning trading could lead to a shift within the international competition (Swiss Banking Association, 2017). Due to this, Switzerland is required to closely monitor developments in the shaping of international conditions and, if necessary, to seek adjustments to strengthen its 
competitiveness (Swiss Banking

Association, 2017).

\section{Digitalization}

Digital change offers many opportunities not only for the financial sector, but also for the whole Swiss economy. The Swiss government has concluded that Switzerland is well prepared to assert itself with regard to digital structural change. The expectation of just a few years ago that fintech start-ups with their potential for disruption would replace banks has disappeared (Sigg, Umbricht, Grimm, \& Kley, 2017). Recently, a strong trend towards cooperation between fintechs and banks has been observed. Through cooperation with start-ups, banks can, thus, expand their service catalogue and realize efficiency gains (Sigg et al., 2017).

In the coming years, more and more freedom-oriented structures will emerge (Sigg et al., 2017). Based on digitalization and globalization, every company is not only competing in regional and national competition, but must increasingly compete with competitors all over the world (Sigg et al., 2017).

On the other hand, digitalization simplifies the relocation of individual departments and business processes by outsourcing activities to supplier companies or countries with lower labor costs than Switzerland. Nevertheless, a lot of investments are necessary to have stateof-the art processes and technology (Grass \& Peters, 2016).

\section{New Employee Skills}

Digitalization also affects the professional profiles of bank employees. This leads to a surplus of vacancies in terms of computer professions. There are not enough job offers for sales representatives (Swiss Banking Association, 2017). It is evident that methodological competence is becoming an increasingly important requirement for future banking specialists (Sigg et al., 2017). Expertise in specific areas remains important but in terms of expertise it must be expanded by knowledge in the technological area (Sigg et al., 2017). In addition, social competences are also becoming more important (Sigg et al., 2017). In order to be able to keep pace with environmental developments, and in the light of the requirements regarding continuous learning and general willingness to change, every individual employee has to grow significantly (Sigg et al., 2017).

\section{Regulation}

Although the competitiveness of Switzerland is still high, the burden associated with regulation density and the resulting costs weighs heavily on the banks (Swiss Banking Association, 2017). Therefore, administrative relief and improvements of existing and future regulation plans are necessary (Swiss Banking Association, 2017). Switzerland wants to ensure equivalence of legislation and is bound by standards such as the Swiss Financial Services Act (FIDLEG) and the Swiss Financial Institutions Act (FINIG) (Swiss Banking Association, 2017). Due to this fact, the Swiss Federal Council adopted standards like FIDLEG and FINIG and made various adjustments and improvements such as excluding insurers from FIDLEG or cancelling the legal relief of financial customers (FIDLEG and FINIG, n.d.). The drafts are now with the Swiss National Council and should be implemented by the beginning of 2019 at the latest.

The new rules which were issued by the Basel Committee back in March 2016, also known as Basel III, originally to be put in force by January 2017, have been postponed indefinitely because of the different positions held by the participants, the US and the EU (FINMA, n.d.).

Since 1 January 2017, the law and its ordinance on the Automatic Exchange of Information (AEOI), which regulates the exchange of accounts and securities deposits of foreign taxpayers between the tax authorities of the participating countries, are in place ("Automatischer 
Informationsaustausch (AIA)", n.d.). The importance of the AEOI for Switzerland is extensive. Approximately a quarter of globally managed assets are based in Switzerland ("Automatischer Informationsaustausch (AIA)", n.d.). Moreover, as an international financial center, Switzerland is committed to a single global standard, according to which all states collect and exchange the same data. The information gained is only used as provided in the agreement to guarantee the confidentiality of the data ("Automatischer Informationsaustausch (AIA)", n.d.).

\section{Th e Budgeting Process in Swiss Banking}

A literature review about IT budgeting processes or methods in the banking sector was conducted for the purpose of this paper to find out whether best practices or other relevant papers for the Swiss banking market already exist. Unfortunately, only theoretical information was found. There is a lack of real case studies that focus on Swiss banking and IT project budgeting processes.

\section{Research Questions}

The aim of this study was to determine the current budgeting process for IT projects in Swiss banks and identify their main challenges. Additionally, the study evaluates banks' ability to react to fastchanging market conditions by means of today's budgeting processes. Therefore, the following research questions were identified:

RQ: Do today's budgeting processes for IT projects support the ability to react to fastchanging market conditions?

RQ1: How is the budgeting process implemented for IT projects in Swiss banks?

RQ2: What are the main problems of today's budgeting process for IT projects?

\section{Method}

To determine the state of today's budgeting processes, an extensive literature review was conducted
(Kornmeier, 2007). As this was the first time for the budgeting process of IT projects in Swiss banks to be investigated, qualitative, semi-structured expert interviews were conducted (Jonker \& Pennink, 2010). Interview requests were sent to 10 of the 15 Swiss top banks according to their balance sheet ("Bildergalerie Ranking", n.d.). The banks were selected out of a basic population of 261 banks in Switzerland.

Five out of these 10 banks agreed to an interview. The interview partners represent a balance sheet of 2,041 billion Swiss francs ("Bildergalerie Ranking”, n.d.). This is approximately $2 / 3$ of the total balance sheet of Swiss banks. Due to privacy reasons, the names of the banks and the interviews themselves were not made public.

For the data collection subject matter experts (SME) were questioned. The interviewed experts have been responsible for a budgeting process within their bank for between two and 11 years. Furthermore, their areas of responsibility include innovation management, digital banking, data analytics, business topics within IT, international trading solutions, or tax reporting. In addition to this, the experts have roles such as head of business development, head of digital banking and data analytics, chief of staff in the IT department, officer responsible for commercial litigation in terms of private customers, and head of IT tax reporting.

The interviews took place between December 2017 and January 2018. They were based on a questionnaire with the following main topics:

1. Current budget process for IT projects

2. Advantages, disadvantages, and challenges of the implemented process

3. Ability of the bank to react to fastchanging market conditions

4. Today's budgeting processes for IT 
projects and their impact on the bank's ability to react to fastchanging markets

5. Trends / future changes in the budgeting process for IT projects

Before the interviews took place, the questionnaire was tested and some changes were made. The average duration of an interview was $45 \mathrm{~min}$. The interviews were recorded, transliterated, encoded, and analyzed (Flick, 2007).

\section{Results}

This study addressed the research questions described in Section 4. The following subchapters contain the results of the interviews with the subject matter experts.

\section{Budgeting Processes for IT Projects in Swiss Banks}

The first aim of this study was to get an overview of the budgeting process within banks in general and to identify the differences between them. There are several similarities between the interviewed banks:

- Similar budget methods

- Budget period: on e year

- $\quad$ Fixed total IT project budget

- Flexible reallocation of funds for projects

- $\quad$ Established IT budget process and committees

- Bottom-up approach

- Prioritization of total budget allocation as an important tool

All interviewees stated that they employ a combination of traditional and better budgeting methods. They stated that they use many aspects of the traditional approach, such as a fixed budget period of one year. Additionally, all banks use zerobased and value-based aspects. They do not use the budget numbers from last year to plan for the next year (zero-based approach). Instead, they allocate the budget based on projects and their expected value. The planning is based on a bottom-up approach.

None of the interviewed banks use rolling budget periods or forecasts. All banks have a fixed budget period from January to December. Projects that last more than one year will be reassessed and revaluated on their business goals every year. The detailed planning process usually starts one year in advance at the earliest and lasts six to twelve months.

The budget is limited to a specific amount of money, regardless of the number, importance, and priority of planned projects. After the collection of all project applications and the creation of a business case, the budget owner prioritizes the project applications and forwards them to a budget committee or board to decide which projects will be financed. At this point, it is important to note that there is always a committee instead of a single person deciding on a budget. After the project budget has been granted, the budget owners are able to start the sourcing process.

The overall IT project budget is usually not changed unless there is a dramatic change in the business environment. As the budget and the forecasts are usually reported monthly or quarterly, reallocations between different projects or programs can be done. According to the interviewees, this process is wellestablished and takes place several times a year.

\section{Differences between Banks}

There are several differences between the interviewed banks:

- $\quad$ Fixed budget cap for several years

- Detailed multiple year planning vs. only detailed oneyear planning for IT projects

- Explicit innovation budget and their business needs 
One bank stated that they have a fixed overall cost budget. This also has an impact on the IT project budget. It has not been changed for a couple of years. Therefore, the prioritization is even more important for this bank as there is no more budget for the following years. On the other hand, there might be less pressure on cost-saving measures according to the interviewee.

Another difference is that some banks have detailed multi-year IT project plans and budgets. Other banks focus on a detailed one-year plan for efficiency reasons.

\section{Advantages}

Most of the interviewed experts see the following advantages of their current budgeting process:

- $\quad$ Efficient

- Well-established

- $\quad$ Flexible

One out of five interviewees agreed that there are not many advantages to the current budget process and that the process is not very satisfactory.

\section{Main Challenges in the Budgeting Process}

This subsection summarizes the problems of the current IT project budget process according to the interviewees. It is important to note that there was no 100 $\%$ consensus concerning the main challenges of the IT project budget process. Open questions as well as closed questions with specific examples were asked during the interviews. The interviewees mentioned the following challenges:

- Accuracy of the plan

- $\quad$ Resources needed to complete the budgeting process

- Difficulty of coordination

- Reallocation and reprioritization process
- Business IT alignment

- Lack of flexibility

Several interviewees mentioned the level of detail in planning, the accuracy, and the resources needed to complete the budgeting. Furthermore, it was mentioned that not only is it difficult to predict the project costs, but also the total cost of ownership (TCO) for a specific application. While not all interviewees considered this topic to be a challenge, for others it was actually one of the main challenges.

One interviewee mentioned the various planning cycles for IT budget planning and line planning. The planning of internal specialist resources and external resources is done separately. This results in an unnecessary coordination task.

As the prioritization task is very important in the budget process, for some interviewees this is a challenge with two aspects. Firstly, the prioritization dialog does not work well enough. Secondly, regions and departments do not feel treated individually. Someone also mentioned that the budgeting process is not strategic enough but more at the functional level than from the perspective of the entire bank. This can lead to prioritization errors.

Another disadvantage is that a budget only acts upwards towards the cost cap and not downwards. This fact leads to no or few incentives for efficiency.

Another issue was identified as the understanding of IT on the business side as well as in the management.

Moreover, the business IT alignment did not work properly.

Even though the budget process starts up to one year in advance, one expert mentioned that the definitive budget would be communicated relatively late in the year. This can lead to short-term staff recruitments towards the end of the year and makes proper resource planning difficult. 


\section{Closed Question Verification}

Table 2 summarizes the answers of the interviewees after the closed questions had been asked. The interviewed experts were asked to evaluate their bank according to the challenges shown in the table below.
During the interview, the challenges were described to the experts so that they could rate their budgeting processes based on the given challenges. They rated the challenges can be rated as follows:

- 1: A challenge:

- $\quad$ 0.5: Somewhat challenging

- 0 : No challenge

- Unknown: If the interviewee was not sure or did not want to give an answer

The three challenges which were partially confirmed by the interviewees are:

- High effort \& cost of planning

- Coordination \& structural challenges

- Accuracy of the plan vs. real implementation

Similar topics had already been mentioned in answering the open questions, but the numbers (on average 0.5 or lower) do not provide a lot of information.

On the other hand, no one confirmed that the allocation of the budget \& resources is a challenge for their bank. So even though prioritization seems to be an issue (according to the answers to the open questions), the interviewees think that the allocation of the budget and the resources are not a challenge. 
Table 2: Identified challenges

\begin{tabular}{|c|c|c|c|c|c|c|}
\hline Bank & 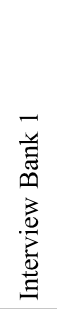 & 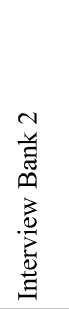 & 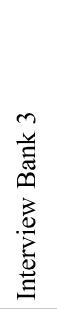 & 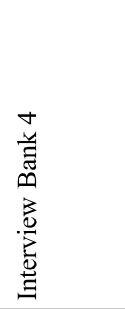 & 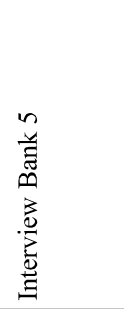 & 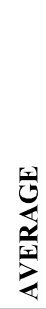 \\
\hline $\begin{array}{l}\text { Low ability to react } \\
\text { to changes }\end{array}$ & 0 & 0 & 0 & 1 & 0 & 0.2 \\
\hline $\begin{array}{l}\text { High effort \& } \\
\text { cost of planning }\end{array}$ & 0.5 & 0 & 0 & 1 & 0.5 & 0.4 \\
\hline $\begin{array}{l}\text { Coordination \& } \\
\text { structural challenges }\end{array}$ & 0.5 & 0 & 0 & 1 & unknown & 0.4 \\
\hline $\begin{array}{l}\text { Accuracy of the plan vs. } \\
\text { real implementation }\end{array}$ & 0 & 1 & 0 & 1 & unknown & 0.5 \\
\hline $\begin{array}{l}\text { No specific innovation } \\
\text { focus/budget }\end{array}$ & 0.5 & 0 & 0 & 0 & 0 & 0.1 \\
\hline Power of responsible managers & 0 & 0 & 0 & 0.5 & 0 & 0.1 \\
\hline Allocation of budget \& resources & 0 & 0 & 0 & unknown & 0 & $\mathbf{0}$ \\
\hline AVERAGE & 0.2 & 0.15 & $\mathbf{0}$ & 0.75 & 0.1 & \\
\hline \multicolumn{7}{|l|}{$\begin{array}{l}\text { Explanation: } \\
1=\text { It is a challenge } \\
0.5=\text { It is partially a challenge } \\
0=\text { It is not a challenge }\end{array}$} \\
\hline
\end{tabular}

The need for a specific innovation budget or innovation focus is not seen as urgent. The power of the responsible manager to influence the budgeting process neither is seen as a big issue, and neither is his or her ability to react to changes.

In general, Table 2 shows that the interviewees do not see a lot of possible challenges. This supports the results of the open questions that the interviewees are quite happy with the current processes.

\section{Ability to React to Fast-Changing Markets}

No interviewee positioned his or her bank as an innovator or laggard in relation to its ability to react to changes.
Additionally, no one could think of an example of a situation where the IT project budget process was a reason for the bank's slow ability to react.

One interviewee mentioned that there is very little connection between the bank's IT budget process and its ability to react to fast-changing markets. Nevertheless, a majority pointed out that sometimes, but not always, the budget process supports the bank's ability to react to fast-changing markets.

A majority of the interviewees identified different challenges that they had to cope with in order to have a better ability to react to fast-changing markets. 
Table 3: Ability to react to fast-changing markets

\begin{tabular}{|l|l|l|l|l|l|l|}
\hline & & & & & & \\
\hline & & & & & \\
Ability to react to \\
changing markets
\end{tabular}

Explanation:

1 = Laggard

2 = Late Majority

$3=$ Early Majority

$4=$ Early Adopter

$5=$ Innovator

The following topics were mentioned most frequently:

- Company culture

- Organization

- Expertise and skills

\section{Optimum IT Budget Process}

Four out of five interviewed experts are satisfied with their current budget process. They only see the need for small adaptations such as:

- Agile project portfolio planning and budgeting

- Specific budget for innovations

- Improved dialog between different stakeholders

Of the five experts, one indicated a preference for a different budgeting method where budgeting is based on the bank's headcount. This leads to less fluctuation in the number of skilled employees and secures a high efficiency and stability.

\section{Conclusion}

The interviews conducted in this study provide an overview of today's budgeting process for IT projects in the Swiss banking sector as well as the challenges involved. For the most part, banks can be said to be prepared for fast-changing markets. A strong relationship between IT project budget processes and the banks' readiness to react to fastchanging markets could not be established. Although all interviewees admitted that it is an expensive and time-consuming process, most of them were confident that the business process is necessary to keep track of a bank's costs and expenses.

The research questions were answered as follows:

Research Question: Do today's budgeting processes for IT projects support the ability to react to fast-changing market conditions?

Answer: There is no significant proof that today's IT project budget process supports the ability of a bank to react to fast-changing markets. Other parameters are more important to secure a high adaptability during changing markets. On the other hand, there is no proof that the IT project budget process prevents flexibility.

Research Question: How is the budgeting process implemented for IT projects in Swiss banks?

Answer: Swiss banks use traditional budgeting methods in combination with better budgeting methods. All the banks use an annual budget and have a maximum planning period of one year. There is no 
beyond budgeting or advanced budgeting method in place.

Research Question: What are the main problems of today's budgeting process for IT projects?

Answer: While most banks are satisfied with their current IT project budget process, the process is not without its challenges, which include:

- Accuracy of the plan vs. real implementation

- High effort \& cost of planning

- Coordination \& structural challenges

- Reallocation and reprioritization process

- Business IT alignment

- Lack of flexibility

\section{Contribution}

This study helps to clarify the influence of the IT budgeting process of Swiss banks on their readiness to react to fastchanging markets. In general, it contributes to highlighting the current situation with regard to IT project budgeting processes in Swiss banks and comparing it with the well-established methods. In addition, it can serve as a basis for learning about new IT budgeting methods and for examining possible implementation.

A strong relationship between IT project budget processes and a bank's readiness to react to fast-changing markets was not found to exist. Other factors such as the culture and structure of the organization als o need to be taken into account. While it was revealed that most banks are satisfied with today's processes, opinions about their challenges vary considerably.

\section{Future Research}

Based on the findings of this study, it is suggested that future research might focus on the following topics, which are more general in nature and do not focus solely on the IT project budget process:

- Agile project portfolio planning and budgeting

- Specific budget for innovation

- Improved dialog between different stakeholders

- $\quad$ Business IT alignment

- Adaption of the culture and organization

\section{References}

1. Automatischer Informationsaustausch (AIA). (n.d.). Retrieved from https://www.efd.admin.ch/efd/de/home/t hemen/wirtschaft-waehrung-

finanzplatz/finanzmarktpolitik/automatische r-informationsaustausch-aia-/fb-AIA.html

2.Swiss Banking Association, S. (2017). Bankenbarometer 2017 Die konjunkturelle Entwicklung der Banken in der Schweiz. Swissbanking. Basel.

3. Bildergalerie Ranking: Das sind die 15 grössten Banken der Schweiz. (n.d.). Retrieved from https://www.handelszeitung.ch/unterneh men/biga-das-sind-die-15-groesstenbanken-der-schweiz-1439631

4. Carlene Cassidy, Kreitner, R., \& Van Huss, S. (2014, February 11). Administrative management: Setting people up for success (1st ed.). Cengage Learning.

5. FIDLEG und FINIG. (n.d.). Retrieved from https://www.efd.admin.ch/efd/de/home /themen/wirtschaft-waehrungfinanzplatz/finanzmarktpolitik/fidlegfinig/fb-fidleg-finig.html

6. FINMA, E. F. (n.d.). Der Basler Ausschuss für Bankenaufsicht [Eidgenössische finanzmarktaufsicht FINMA]. Retrieved from

https://www.finma.ch/de/FINMA/Internatio nale\%20Zusammenarbeit/Policy\%20und\%2 0Regulierungszusammenarbeit/BCBS/

7. Flick, U. (2007, October 1). Qualitative Sozialforschung Eine Einführung. Rororo.

8. Global Wealth 2016: Navigating the New 
Client Landscape. (n.d.). Retrieved from https://www.bcgperspectives.com/conten t/articles/financial-institutions-consumerinsight-global-wealth-2016/

9. Grass, M. \& Peters, M. (2016). Die volkswirtschaftliche Bedeutung des Schweizer Finanzsektors. BAK. Basel. Group, H. (Ed.). (2005). Planning on the move! Eschborn.

10. Jonker, J. \& Pennink, B. (2010). The essence of research methodology: $A$ concise guide for master and phd students in managementscience. Berlin: Springer.

11. Kornmeier, M. (2007). Wissenschaftstheorie und wissenschaftliches Arbeiten (1st ed.). Heidelberg: PhysicaVerlag.

12. Mejzini, N. \& Seidel, H. (2015). Challenging the principles of the beyond budgeting model. Karlstad Business School. Karlstad.

13. Mitchell, M. (2005). Beyond budgeting: Case studies in North American financial services. Journal of Performance Management, 18(1), 3.

14. Pidgeon, C. (2010). Methods of budgeting. Research and Library Services Northern Ireland Assembly. Belfast. Pietrzak

15. bibinitperiod. (2013). Traditional versus activity-based budgeting in nonmanufacturing companies. Social Sciences, 82(4), 26-37.

16. Rickards, R. C. (2006). Beyond budgeting: Boon or boondoggle. Investment Management and Financial Innovations, 3(2), 62-76.

17. Rickards, R. C. (2008, September 19). An endless debate: The sense and nonsense of budgeting. International
Journal of Productivity and Performance

Management, 57 (7), 569-592. doi:10.1108/17410400810904038

18. Rieg, R. (2015). Planung und Budgetierung. DOI: 10.1007/978-3-83494629-4. Wiesbaden: Gabler Verlag.

19. Retrieved from http://link.springer.com/10.1007/978-38349-4629-4

20. Rivero, E. J. R. (2013). In which direction is budgeting moving? A report from large firms of Spain. Facultad de Ciencias Económicas y Empresariales, Universidad de Extremadura.

21. Rümmler, R., Toggwyler, A., Bollag, M., \& Nicollier, J.-F. (2013). Information technology in Swiss private banking. Ernst \& Young.

22. Sigg, A., Umbricht, R., Grimm, S., \& Kley, C. (2017). Zukunftsstudie Bankfachspezialisten 2030.

23. State Secretariat for International Finance (SIF). Finanzmarktpolitik für einen wettbewerbsfähigen Finanzplatz Schweiz. (2016). Bern.

24. State Secretariat for International Finance (SIF). Kennzahlen Finanzstandort Schweiz (Oktober 2017). Retrieved from https://www.efd.admin.ch/efd/de/home/ dokumentation/nsb-news_list.msg-id68319.html

25. Swiss Banking Association. (2015). Agenda für einen wettbewerbsfähigen, vielfältigen und leistungsstarken Bankensektor. Swissbanking. Basel.

26. Tanase, G. L. (2014). Difficulties of the budgeting process and factors leading to the decision to implement this management tool. Procedia Economics and Finance. Bucharest. 